can be seized with pre- and hence their extremicision, and large ones sup- ties are more appropriately ported firmly.

called graspers than hands, intended for clinging round branches of trees, \&c., and are not adapted for the varied actions performed by the hand of man; hence the four hands of apes do not furnish them with a character superior to man, but rather serve as a link between the mere organs of support in lower animals, and the true hand found only in man, the graspers performing the double office of support and prehension.

The posterior position of the foramen magnum in man, rather more than compensates for the greater lightness of the anterior part of the skull, so that the head would fall forwards if unsupported. The greater strength of the posterior muscles of the head, however, renders the effort to support it very slight. The pro. cesses of the lumbar vertebræ are much developed in man, and give attachment to the powerful muscles of the back, thus serving to overcome the tendency of the viscera from their weight to draw the body forward, but in the dorsal and cervical region there is far less strength. The reverse is observed in other mammalia, for in them the spinous processes of the cervical and dorsal vertebre are large and strong for the attachment of the ligamentum nuchæ to support the head. The great breadth of the pelvis in man gives a wide basis of support. Except in the kangaron, the lower extremities of man are proportionably longer than in any other mammalia; the length of the thighs and comparative shortness of the arms particularly characterize man, his hands only reach to the middle of the thighs; but in the chimpanzee they are as low as the knees, and in the orang down to the ankles. From the obliquity in the direction of the femur, the knees are brought close under the centre of gravity of the body, and thus in alternately supporting the whole weight on one leg in walking, a steady position is maintained, but if the knees were far apart the whole body would be swung from side to side at each step, as is seen in the shuffling walk of women, owing to the great : breadth of their pelvis. Man is the only mammalia that can stand on one leg, owing to the strength and size of his foot. The lateral expansion of the chest is peculiar to man, and the higher monkey.

These characters establish the conclusion, that man is naturally a biped, and conformed to the erect attitude. But the most anthropoid apes cannot move with ease and agility without using all their limbs.

Man's superiority is due to his mind and its instruments conjointly. His teeth are equal in length, and are all closely approximated,* and vertical in their direction, hence the prominence of the chin. The brain is large and complex in structure. The powers of comparing his sensations, and drawing conclusions

- These characters distinguish hin from all other animals, except the fossil anoplotherium, (allied to the tapir tribe.) from this mental process, and of adapting himself to circumstances, are highly developed in man. Lastly, we observe, that the growth is slower, and the dependence on the parent longer, than in any other species of living being. Articulate sounds or language are peculiar to man. The reasoning powers differ rather in degree than in kind from those of the inferior aximals. But man seems distinguished by one innate tendency, viz., to believe in some unseen existence. All races have this tendency, and a desire to share in this spiritual existence. Thus, in the words of Pope, we may conclude, that-

"Man's the noblest work of God."

\section{CASE OF PURPURA HEMORRHAGICA.}

TO THE EDITOR OF THE PROVINCIAL MEDICAL AND

Sir, SURGICAL JOURNAL.

If you deem the following case of purpura hæmorrhagica of sufficient interest, may I beg the insertion of it in the Journal?

I remain, Sir,

Your obedient servant, JOHN BARCLAY, M.D.

Leicester, May 10, 1845.

On the 23rd of last April I saw, accidentally, with Mr. Buck, (who kindly permits the publication of the following notes,) a Union patient, to whom he had just been suminoned.

Mary Johnstone, aged 11, a fair and stout child, living in a low situation, and in a neighbourhood where some cases of small pox, and a good many of the worst form of typhus, were then occurring. She had been ailing for four or five weeks, and had kept her bed for ten days, having been prescribed for by an irregular practitioner. She had complained of headache and thirst; and the bowels had been opened by medicine. About one, p.m., of the preceding day, ('Tuesday,) she began to bleed at the nose and lips; and on Wednesday norning romited a quantity of dark blood four or five times. (The mother states there was about a teacupful each time.) She had also had three copious and most offensive stools that morning, consisting of black clotted blood.

At eleven, a.m., we found the patient pale, but with a flush on the cheek; skin very hot and harsh; breathing rapid; pulse 140; small and compressible; the tongue bloodless, and furred at the back part; and the abdomen tympanitic. The blood was draining down in a sinall continuous stream from the nostrils, as she lay on her back; and on the arms, thighs, and abdomen, were many sinall spots of purpura, very beautifully marked, the largest being about two lines in diameter; on one arm was a large vibex. Some wine was administered immediately, and Mr. Buck agreed to try the following:-To take a powder of gallic acid of five grains, white sugar ten grains, every four hours, and a stimulant mixture, with carbonate of ammonia.

About one, p.m., the bleeding at the nose ceased, after lasting twenty-four hours. At five she had another stool of the same nature as the previous ones. The third and fourth powders produced sickness, and only her drinks, without any blood, were rejected. 
On Thursday she continued much in the same state. She was directed to continue the powders, which had been temporarily suspended on account of the vomiting; and a sinapism was applied to the abdomen.

Friday, 25th. She had taken one drachm of the gallic acid, and seemed decidedly better. The pulse vas 120 ; the tongue covered with a brown fur, and the abdomen was still tympanitic. The spots continued as brilliant us before, and" her arm showed a very marked discolouration at a part which had been purposely pinched the day before. She was directed to omit the powders and continue the stimulant mixture.

From this time she went on improving; the spots gradually lost their brilliancy, and disappeared of a light brown colour, being still perceptible ten days after her seizure, when she was up, and taking tonics and light nourishment. The bowels and skin acted very freely after the first week, and she is now (May 4th,) quite well.

\section{CASE OF DISLOCATION UF THE FEMUR.}

TO THE EDITOR OF THE PROVINCIAL MEDICAL ANM Sir, SURGICAL JOURNAL.

Should you consider the accompanying case worth recording, I should be obliged by your giving it a place in your valuable Journal, the chief motive for my recording it is, that it may act as a beacon to my surgical brethren, and induce them to make a strict examination into every case of accident, however trifling it may at first appear.

Yours very truly,

$$
\text { F. WELSH. }
$$

Ledbury Dispensary, May 6, 1845.

Thomas Mason, aged 28, was partially buried by a bank of earth fulling on him whilst he was undernining it. I saw him a few hours after the accident; his only complaint was of slight pain in the back and knee, but as there appeared no distortion of the limb, as it lay flexed upon the other, and flexion and extension were not much impeded, I considered it a mere bruise, and treated it accordingly. At the end of a fortnight, I saw him aguin, his report of himself was that he was much better, had been up, and said that with a strengthening plaster he should be quite well. Anxious to see how he could walk, I made him get up, when at once the nature of the accident was too evident, namely, dislocation of the femur on the dorsum ilii. With the kind and able assistance of $\mathrm{Mr}$. Webb and Mr. Wood, the pullies were applied; we gave him tartrate of antimony, three grains, tincture of opiun forty drops; steady traction was kept up for twenty minutes, when the bone (with some manipulation).was happily reduced. I may observe the patient was rather under the middle stature, though muscular.

\section{PROVINCIAL ftitedical \& Eurgícal Эournal.} WEDNESDAY, MAY 21, 1845.

On Thursday last Mr. Wakley brought under the consideration of the House of Commons the conduct of the Council of the College of Surgeons, in reference to their general management of the concerns of the College, and especially to the appointment of fellows under the provisions of the new charter. He concluded by moving two resolutions, inculpating the management of the Royal College, and calling for investigation into the circunstances which led to the grant of the charter of 1843 , and into the effects produced by its operation on the profession at large. If those resolutions were negatived, he expressed his intention to propose another resolution, on which he would take the sense of the House, to this effect:-

"That in any charter which the Crown might be advised to grant for the incorporation of the general practitioners, those gentlemen were fully entitled to enjoy an equality of professional station with the newly-created fellows, and that a deep and lasting injury would be inflicted on many thousands of scientific men, if a College of General Practitioners were to be founded as an institution inferior to the College of Surgeons."

"The House was immediately afterwards counted out!

We are far from considering it necessary that the honourable members to whom the duty of legislating for the general interests of this country is intrusted, should be compelled night after night to listen to all the verbiage with which so many of their number contrive to obscure intelligible propositions, or in more doubtful questions,-

"To make that dark which was dark enough without ;" but we do protest against the disposal after this very summary fashion of a question of real importance to the great mass of the population, and in reference to which, the opinion of a numerous intelligent body of those more especially, or rather more immediately interested in it, has been so generally expressed.

If there be any one point on which the feeling of the profession is entitled to be considered all but unanimous, it is that which regards the treatment of the great body of the existing members of the College of Surgeons under the Neiv Charter. To call this Charter the Charter of the College of Surgeons of England is a glaring misnomer; it is neither more nor less than the Charter of a small number of irresporsible individuals, in whom the government of the London College was vested at the time, and was obtained by them under the false pretence of the Council representing the College, 